DOI 10.37882/2223-2966.2020.10.11

\title{
МИКРОБИОЛОГИЧЕСКАЯ И ОРГАНОЛЕПТИЧЕСКАЯ ОЦЕНКА КОЛБАС, РЕАЛИЗУЕМЫХ В ТЮМЕНСКОЙ РОЗНИЧНОЙ СЕТИ
}

\section{MICROBIOLOGICAL AND ORGANOLEPTIC EVALUATION OF SAUSAGES REALIZED IN TYUMEN RETAIL NETWORK}

\section{Domatskiy}

M. Mikhailov

Summary: The article considers the results of the veterinary and sanitary assessment of the quality of sausages sold in the retail trade network of the city of Tyumen. When conducting research, organoleptic and microbiological (microscopy, culture) methods were used. Sausages provided for veterinary and sanitary examination were examined for the content of mesophilic aerobic and facultative anaerobic microorganisms, bacteria of the Escherichia coli group, Salmonella and Listeria, sulfitereducing clostridia, and staphylococci.

As a result of microbiological research, 235 samples of sausages, 228 turned out to be negative and 7 ( 2 samples of cooked sausage "Dietetic" and 1 sample of half-smoked sausages "Village", "Polar", "Chopped" and "Odessa" - 2 sample) with positive. In all positive samples, $1 \mathrm{~g}$ of the test product revealed BGHC, and in two of them staphylococcus was also found.

When organoleptic evaluation of 4 samples of cooked sausage «Russian» category B, the compliance of the main quality indicators (appearance, smell, taste, consistency) with the requirements of GOST R 52196-2011 was established.

There was no deviation from the required content of sodium nitrite and sodium chloride, and the amount of protein was less in only one sample. Microscopic examination of preparations-prints of the deep and surface layer of sausages revealed no microorganisms.

During the microbiological analysis of 4 samples of sausages, mesophilic aerobic and facultative anaerobic microorganisms were found in the

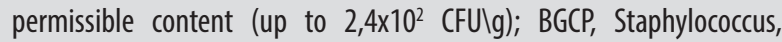
Salmonella, Listeria and sulfitreducing Clostridium were not established, which meets the microbiological standards of good-quality cooked sausages.

Keywords: sausages, microbiological assessment, organoleptic indicators.

\author{
Домацкий Владимир Николаевич \\ д.б.н., професссор, ФГБОУ ВО «Государственный аграрный \\ университет Северного Зауралья» \\ domatskiyvn@gausz.ru \\ Михайлов Михаил Владимирович \\ ФГБОУ ВО «Государственный аграрный университет \\ Северного Зауралья»
}

Аннотация: В статье рассматривается результаты ветеринарно-санитарной оценки качества колбас, реализуемых в розничной торговой сети г. Тюмени. При проведении исследований применяли органолептический и микробиологический (микроскопия, посевы) методы исследования. Колбасы, предоставленные для проведения ветеринарно-санитарной экспертизы, были исследованы на содержание мезофильных аэробных и факультативно-анаэробных микроорганизмов, бактерий группы кишечной палочки, сальмонелл и листерий, сульфитредуцирующих клостридий и стафилококков.

В результате микробиологического исследования 235 образцов колбас, 228 оказались с отрицательными результатами и 7 (2 пробы варёной колбасы «Диетическая» и по 1 пробе полукопчёных колбас «Деревенская», «Полярная», «Рубленная» и «Одесская» - 2 пробы) с положительными. Во всех положительных образцах в 1 г исследуемого продукта обнаружены БГКП, а в двух из них обнаружен ещё и стафилококк.

При органолептической оценке 4 образцов вареной колбасы «Русская» категории Б установлено соответствие основных качественных показателей (внешний вид, запах, вкус, консистенция) требованиям ГОСТа Р 52196-2011. Не установлено отклонения от требуемого содержания нитрита натрия и хлористого натрия, а количество белка было меньше лишь в одной пробе. При микроскопическом исследовании препаратов-отпечатков глубинного и поверхностного слоя колбас микроорганизмы не были выявлены.

В ходе микробиологического анализа 4 образцов колбас обнаружены мезофильные аэробные и факультативно-анаэробные микроорганизмы в допустимом содержании (до 2,4х10² KOElг); БГКП, стафилококк, сальмонелла, листерия и сульфитредуцирующие клостридии не установлены, что отвечает микробиологическим нормативам доброкачественных варёных колбас.

Ключевые слова: колбасы, микробиологическая оценка, органолептические показатели.

носятся к продуктам, пользующихся особым спросом у населения. В состав колбас входит мясной фарш, соль и специи, которые после специальной технологии перерабатываются в готовый к употреблению продукт. Колбасы используются в рационе человека, без какой-либо термической обработки. Учитывая тот факт, что варёные колбасы - это продукты, употребляемые большинством населения, то в технологическом процессе их производства требуется выдержать баланс между белками и жирами, влажностью и сухими веществами, которые содер- 
жатся в мясе, используемом для приготовления колбас. Модернизация производственных процессов переработки мясного сырья, используемого для производства колбасных изделий, а также совершенствование технологических режимов предусматривающих внесения различных дополнительных ингредиентов, которые способствуют значительному увеличению объёма выпускаемой продукции, влечёт за собой опасность снижение качества колбасных изделий. В связи с этим повышение качества производимой продукции приобретает первоочередной значение $[1,4]$.

Немаловажное значение имеет оценка безопасности готовой продукции, перед тем как она попадет к потребителю. В процессе производства колбасных изделий происходит процесс созревания фарша, что может способствовать росту и развитию разных, в том числе и патогенных микроорганизмов, например группы кишечной палочки и сальмонелл, которые могут вызывать пищевые токсикоинфекции после её употребления [2,3].

Исходя из этого, нами была определена цель работы: провести оценку микробиологической обсеменённости колбас, реализуемых в розничной сети г. Тюмени.

Для этого были поставлены следующие задачи:

- проанализировать результаты микробиологической оценки колбас в ГАУ ТО «Тюменская областная ветеринарная лаборатория»;

- провести органолептическую оценку варёной колбасы;

- провести микроскопическое изучение препаратов-отпечатков;

- определить содержание мезофильных аэробных и факультативно-анаэробных микроорганизмов (КМАФАнМ) в 1 г продукта;

- исследовать опытные образцы на наличие в них бактерий группы кишечной палочки (БГКП), Listeria monocytogenes, Salmonella, Staphylococcus aureus и сульфитредуцирующих бактерий.

\section{Материал и методы}

Работа выполнена в отделе микробиологии ГАУ ТО «Тюменская областная ветеринарная лаборатория».

Все исследования проводили согласно действующим методикам выполнения лабораторного анализа качества пищевых продуктов, указанных в соответствующих нормативно-технических документах.

Анализ результатов ветеринарно-санитарной экспертизы варёных, копчёных и полукопчёных колбас осуществляли на основании данных журнала регистрации микробиологических исследований ГАУ ТО «ТОВЛ» за 2019 г. и собственных исследований.
Вместе с тем провели исследования 4 аналогичных из одной партии образцов варёной колбасы «Русская» категории Б, согласно ГОСТ Р 51447-99 [5].

При проведении ветеринарно-санитарной оценки применяли органолептический и микробиологический (микроскопия, посевы) методы исследования.

Оценивая органолептические показатели (внешний вид, консистенция, запах и вкус) колбас определяли их соответствие условиям ГОСТ Р 52196-2017 и ГОСТ 23670$2019[6,7]$.

При микроскопическом исследовании препаратовотпечатков исследуемых образцов колбас делали окраску по Граму и исследовали под иммерсией не менее 25 полей зрения.

Для оценки микробной обсеменённости использовали показатели:

- содержание мезофильных аэробных и факультативно-анаэробных микроорганизмов в 1 г продукта;

- присутствие бактерий группы кишечной палочки в 1 г;

- бактерий рода Salmonella в 25 г;

- Listeria monocytogenes в 25 г;

- Staphylococcus aureus в 1 г;

- сульфитредуцирующих клостридий в 0,1 г колбаcы.

С целью проведения исследований колбас осуществляли изъятие образцов по ГОСТу 9792-73. Затем общую навеску массой 50 г приготовили из отдельных образцов в следующем порядке:

1. Образцы колбас помещали в металлическую кювету, обрабатывали ватно-спиртовым тампоном и два раза обжигали над огнём спиртовки.

2. После этого проводили разрез колбасы в продольном направлении обеззараженным ножом на две равные половины и отбирали пробные кусочки из различных частей.

3. От общей массы отбирали кусочки по 20 г. и помещали в металлическую ёмкость.

4. После этого кусочки проб переносили в обеззараженную фарфоровую ступку с 2-3 г стерильного песка, постепенно перемешивая и приливая 80 мл натрия хлорида.

5. Затем взвесь оставляли на 15 минут при температуре $18-20^{\circ} \mathrm{C}$ и обеззараженной пипеткой проводили отбор содержимого для высева на специальные питательные среды.

\section{Результаты исследований}

Результаты изучения ветеринарно-санитарной оцен- 
ки колбас, проведенных в лаборатории микробиологии ГАУ ТО «ТОВЛ» в 2019 г. показали, что для экспертизы было представлено 235 образцов колбас, из них 126 варёных, 42 варено-копчёных, 7 ливерной, 36 полукопченых и по 12 сырокопченой и сыровяленой. Из 235 образцов колбас 228 были с отрицательными результатами и 7 (2 пробы вареной колбасы «Диетическая» и по 1 пробе полукопчёных колбас «Деревенская», «Полярная», «Рубленная» и «Одесская» - 2 пробы) с положительными. Во всех положительных случаях исследуемого образца были обнаружены БГКП, а в двух из них («Диетическая» и полукопченая колбаса: «Одесская») обнаружен Staphylococcus aureus.

Для проведения органолептической экспертизы 4 образцов варёной колбасы «Русская» категории Б использовали цельный и разрезанный батон. Оценку проводили следующим образом: визуально оценивали внешний вид, цвет и состояние поверхностного слоя; запах определяли снаружи и в толще батона, используя деревянную шпажку, которую продвигали в глубину образца; консистенцию устанавливали нажатием пальцами на исследуемый образец; вкус устанавливали апробацией колбасы.

В ходе исследования было установлено, что по внешнему виду колбасы имеют чистую поверхность и довольно упругую консистенцию. Цвет их при разрезе был бледно-розовый, отмечали наличие небольших комочков шпика белого цвета размером не более 4 мм, внутренняя структура батона была однородная.

При оценке вкусовых качеств и запаха установлено полное их соответствие заявленному типу колбасы. Присутствовал специфический аромат пряностей, вкус приятный, слегка солоноватый. Проведённые исследования показали соответствие образцов требованиям стандарта, предъявляемых к свежей колбасе.

Одним из важных показателей качества колбасы является содержание нитрита натрия и хлористого натрия. По результатам оценки не было установлено превышение нормативов - свыше 0,005\%, а содержание варьировалось в пределах 0,003-0,004\% и не более 2,4\% при показателях 2,1-2,3\% соответственно.

Также провели оценку содержания в образцах колбасы остаточной кислой фосфатазы. В результате было установлено, что этот показатель не превышает требуемый норматив, составляющий 0,006\%.

Определение количества белка в составе колбас является наиболее значимым показателем, характеризующим пищевую ценность продукта. В соответствии с нормативно-технической документацией содержание массовой доли белка обязано быть не меньше 10\%. В первом образце колбасы было установлено недостаточное количество белка, составляющее 9,2\%. Уменьшение массовой доли белка подтверждает снижение биологической, пищевой и энергетической ценности продукта. В остальных образцах колбас содержание белка было более $10 \%$ и составляло 10,3 - 10,8\%, что соответствовало нормативно-техническим показателям качественных продуктов.

Микроскопическое изучение препаратов - отпечатков. Для приготовления препаратов-отпечатков колбасы стерильными ножницами вырезали из поверхностного и глубинного слоя каждого образца кусочек размером $1,5 \times 2$ × 2,5 см и прикладывали к предметному стеклу местом свежего среза, сделав по три отпечатка на двух предметных стёклах.

Препараты-отпечатки высушили, зафиксировали и окрасили по Граму. Под иммерсией исследовали 25 полей зрения.

Результаты микроскопического исследования: отпечатки колбас на стекле заметны. Окраска мазков удовлетворительная. В препаратах-отпечатках образцов из глубинного и поверхностного слоя микробов не выявлено.

Содержание КМАФАнМ в 1,0 г пробы составляло

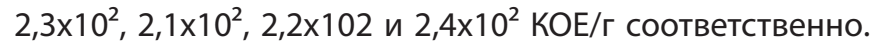
Таким образом, результаты анализов показали соответствие показателей ГОСТу 10444.15-94, где содержание микроорганизмов для варёных колбас категории Б не может быть больше значения $2,5 \times 10^{3} \mathrm{KOE} /$ г.

Определение количества БГКП в 1,0 г колбас показало, что все пробы данной партии были отрицательные. По ГОСТу 31747-2012 в 1 г продукта не допускается наличие БГКП. Также не выявлено и сальмонелл.

Определение наличия листерий показало, что во всех образцах роста бактерий не наблюдали, листерии не выявлены. Отрицательный результат получен и при определении на стафилококк. Согласно ГОСТу 31746-2012 в 1 г пробы не должно быть присутствие стафилококков.

Анализ результатов определения наличия сульфитредуцирующих клостридий в исследуемых образцах показал их отсутствие. По ГОСТу 29185-2014 в 0,1 г продукта не должно быть присутствие этих микроорганизмов.

\section{Обсужкение результатов.}

От качества продуктов питания во многом зависит здоровье людей. Используемые в настоящее время продукты питания должны в полной мере соответствовать 
современным требованиям Технического регламента Таможенного союза «О безопасности пищевых продуктов». Однако, производители продуктов питания не всегда в полной мере соблюдают требования нормативно-технической документации.

Нами проанализированы и исследованы колбасы, поступающие для реализации в розничную торговую сеть г. Тюмени. Результаты проведенных микробиологических и органолептических исследований позволяют сделать заключение о том, что, в основном, все колбасы соответствуют требованиям нормативно-технической документации. Всего 7 образцов (2,98\%) из 235 (2 пробы варёной колбасы «Диетическая» и по 1 пробе полукопчёных колбас «Деревенская», «Полярная», «Рубленная» и «Одесская» - 2 пробы) оказались положительными. Во всех положительных образцах в 1 г исследуемого продукта обнаружены БГКП, а в двух из них обнаружен ещё и стафилококк. Следовательно, производителям колбас необходимо более качественно проводить внутренний ветеринарно-санитарный контроль производимой продукции, особенно по микробиологическим показателям, а торговым предприятиям соблюдать рекомендуемые режимы хранения и реализации продукции.

\section{Выводы}

Колбасы, реализуемые в розничной торговле г. Тюмени и предоставленные для проведения ветеринарно-санитарной экспертизы, были исследованы на содержание мезофильных аэробных и факультативно-анаэробных микроорганизмов, бактерий группы кишечной палоч- ки, сальмонелл и листерий, сульфитредуцирующих клостридий и стафилококков.

В результате микробиологического исследования 235 образцов колбас, 228 оказались с отрицательными результатами и 7 (2 пробы варёной колбасы «Диетическая» и по 1 пробе полукопчёных колбас «Деревенская», «Полярная», «Рубленная» и «Одесская» - 2 пробы) с положительными. Во всех положительных образцах в 1 г исследуемого продукта обнаружены БГКП, а в двух из них обнаружен ещё и стафилококк.

При органолептической оценке 4 образцов вареной колбасы «Русская» категории Б установлено соответствие важнейших качественных показателей (внешний вид, запах, вкус, консистенция) требованиям ГОСТа Р 52196-2011.

Не установлено отклонения от требуемого содержания нитрита натрия и хлористого натрия, а количество белка было меньше лишь в одной пробе.

При микроскопическом исследовании препаратовотпечатков глубинного и поверхностного слоя колбас микроорганизмы не были выявлены.

В ходе микробиологического анализа 4 образцов колбас обнаружены мезофильные аэробные и факультативно-анаэробные микроорганизмы в допустимом

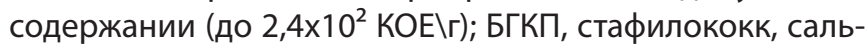
монелла, листерия и сульфитредуцирующие клостридии не установлены, что отвечает микробиологическим нормативам доброкачественных варёных колбас.

\section{ЛИТЕРАТУРА}

1. Домацкий В.Н., Белецкая Н.И. Микробиологический анализ колбасы варёной «Молочная» // Сборник статей Всероссийской научной конференции современные научно-практические решения в АПК. Тюмень 8 декабря 2017 г. Часть 1.- С. 210-215.

2. Криштафович В.И., Колобов С.В. Методы и техническое обеспечение контроля качества (продовольственные товары). //Учебное пособие. - М.: ИК «Дашков и К», 2006. - 256с.

3. Руководство по микробиологии и иммунологии / Н.М. Колычев, В.Н. Кисленко, Р.Г. Госманов, В.И. Плешакова, О.П. Колесникова, Л.Ф. Зыкин, Л.Г. Белов // Новосибирск: Арта, 2010. - 256с.

4. Микробиология, санитария, гигиена / К.А. Мудрецова-Висс и др. // - М.: Издательский Дом «Деловая литература», 2008. - 400с.

5. ГОСТ Р 51447-99 (ИСО 3100-1-91) Мясо и мясные продукты. Методы отбора проб. М. Издательство стандартов, 2000.

6. ГОСТ Р 52196-2017 Изделия колбасные варёные мясные. Технические условия. М. Стандартинформ, 2018.

7. Гост 23670-2019 Изделия колбасные варёные мясные. Технические условия. М. Стандартинформ, 2019.

(с) Домацкий Владимир Николаевич (domatskiyvn@gausz.ru), Михайлов Михаил Владимирович. 